\title{
Promoting careers in library and information science
}

\author{
By Sharon Vaughters
}

\section{A career counselor's perspective}

$\mathbf{L}$

ibrarians and career professionals have some things in common when it comes to educating students about who we are and what we do. Because our work is situated on campus, we probably share a similar frustration of having many students use our services (in the case of libraries the service is an integral part of the academic experience), and few students having more than a surface knowledge about what we do as professionals. We also each have an opportunity to interact with students as they work in our units. And, because we do not have a popular television show showcasing our work, we can safely conclude that we don't have the media coverage that doctors, lawyers, or business executives enjoy.

Building effective marketing strategies can help enhance the possibility of recruiting the "best and the brightest" to the profession. In order to educate students about career opportunities in information and library science, having a knowledge base of how students learn and make decisions about careers can be extremely helpful. The following perspective on how to attract students is grounded in information about the complexity of that process.

Although there are many schools of thought about how people make career decisions, most perspectives include a process whereby an individual integrates knowledge about oneself with information about career options and makes some sort of commitment to a choice by taking steps to implement it. Therefore, a student making the decision to enter a library graduate program may progress through a number of overlapping stages.

First, he or she may start by considering his or her own skills, interests, and values by self reflection, talking with a counselor or trusted friend or role model, working with counseling tools such as a career "test" or interactive computer guidance system, or by attending a career decision-making workshop.

Second, the student may talk with a librarian to gain the perspective of someone in the field, read occupational information on careers in the library or information fields, attend a program on career opportunities with a graduate degree, or sit in on a graduate class to find out about a field of interest.

Third, after making some level of commitment, the student may test out the option by working part-time or in a summer job or internship and, based on that information, either confirm or cast doubt on the choice they have made. And finally, if the choice seems reasonable or "feels right," the student may make the commitment to go to graduate school and start the process of exploration all over again as they make a choice about appropriate programs. Career professionals facilitate this process by providing information about the many career opportunities, helping interpret information and offering the information in a format that suits the student's individual style.

Many different factors influence the process of career decision-making. The perceptions or information a student has about a career can be based in myth or in reality. When attempting to educate a student, one is therefore faced with the challenge of dispelling myths and providing a realistic view of the profession. When Hollywood depicts a librarian, the information 


\section{Cost-effective access to scientific literature in 35 fields}

$\mathrm{H}$

ow can you give your patrons comprehensive access to current scientific literature in a wide range of fields?

Cambridge Scientific Abstracts journals provide a solution to this dilemma with 35 journals that cover major disciplines in the life sciences, environmental sciences, technology, and management.

By supplementing

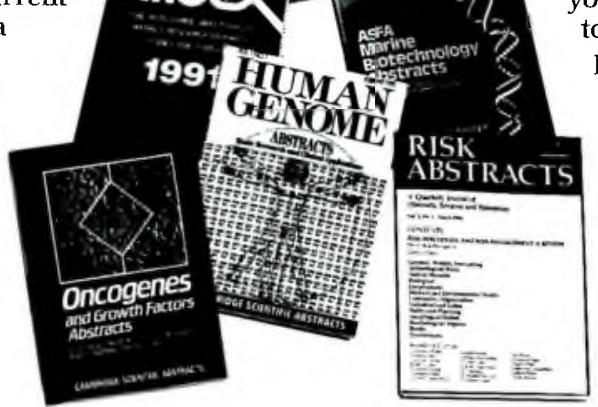

your full-text subscriptions, Cambridge journals give you a cost-effective means to cover thousands of publications... so your patrons can keep up with important global research. These journals provide informative abstracts drawn from up to 5,500 worldwide publications, as well as comprehensive indexing to help you find specific information fast.

\section{Medical and Bioloyical Sciences}

$\square$ Biochemistry Abstracts, Part 1: Biological Membranes Monthly

$\square$ Biochemistry Abstracts, Part 2: Nucleic Acids Monthly

$\square$ Biochemistry Abstracts, Part 3: Amino Acids, Peptides \& Proteins Monthly

$\square$ Biotechnology Research Abstracts Bimonthly

$\square$ Calcified Tissue Abstracts Quarterly

$\square$ Chemoreception Abstracts Quarterly

$\square$ Genetics Abstracts Monthly

$\square$ RP Human Genome Abstracts Bimonthly

$\square$ Immunology Abstracts Monthly

$\square$ Microbiology Abstracts, Section A: Industrial $\mathscr{S}^{\circ}$ Applied Microbiology Monthly

$\square$ Microbiology Abstracts, Section B: Bacteriology Monthly

$\square$ Microbiology Abstracts, Section C: Algology, Mycology \& Protozoology Monthly

$\square$ Neurosciences Abstracts Monthly

$\square$ RP Oncogenes \& Growth Factors Abstracts Quarterly

$\square$ Toxicology Abstracts Monthly

$\square$ Virology \& AIDS Abstracts Monthly

RP: Recently Published

NE: Newty Expanded
Fisheries, Aquatic Seiences, and Zoology

$\square$ Animal Behavior Abstracts Quarterly

$\square$ Aquatic Sciences \& Fisheries Abstracts (ASFA), Part 1:

Biological Sciences \& Living Resources Monthly

$\square$ Aquatic Sciences \& Fisheries Abstracts (ASFA), Part 2: Ocean Technology, Policy \& NonLiving Resources Monthly

$\square$ RP Aquatic Sciences \& Fisheries Abstracts (ASFA), Part 3: Aquatic Pollution \&o Environmental Quality Bimonthly

$\square$ NE ASEA Aquaculture Abstracts Bimonthly

$\square$ RP ASFA Marine Biotechnology Abstracts Quarterly

$\square$ Entomology Abstracts Monthly

$\square$ Oceanic Abstracts Bimonthly

For more information or a sample copy, write or fax today:

$$
\text { (301) 961-6720 }
$$

Attention:Marketing Department

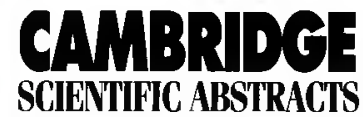

A Division of Cambridge Information Group 7200 Wisconsin Avenue

Bethesda, Maryland 20814-4823 USA
Pollution and the Envioument

$\square$ RP ASFA Part 3: Aquatic Pollution $₫$ Environmental Quality Bimonthly

$\square$ Digests of Environmental Impact Statements Bimonthly $\square$ Ecology Abstracts Monthly $\square$ Pollution Abstracts Bimonthly

Engineering, Computer Science. and Market Research

$\square$ Computer \& Information Systems Abstracts Monthly

$\square$ Conference Papers Index Bimonthly

$\square$ Electronics \& Communications Abstracts Bimonthly

$\square$ RP FINDEX: The Worldwide Directory of Market Research Reports, Studies \& 0 Surveys Semiannual

$\square$ Health \& Safety Science Abstracts Quarterly

$\square$ ISMEC: Mechanical Engineering Abstracts Bimonthly

$\square$ RP Risk Abstracts Quarterly

$\square$ Solid State $\&$ Superconductivity Abstracts Quarterly

\section{Magnetic 'Tape Inalabase.}

Most of the journals listed here are available on magnetic tape for your Local Area Network. For more information or to obtain a sample tape, please fax or write on your official letterhead. 


\section{Refiections on my recruitment}

I was a social change and development major with a business administration minor. Aspiring to become an attorney, I became disillusioned with law as an occupation. I found most of what I was studying interesting; I was one of those students who thirsted for information. Whenever I researched in the library I was seduced by the potential of so much knowledge and information. I often lost all track of time. As I began to think about graduate programs I could not commit to one discipline. I turned to career counseling. I took the Strong Campbell Interest Inventory and the MMPI. Librarian was one of the results. I laughed.

The facilitator encouraged me to talk to a few of my professors about librarianship in order to broaden my experiential base. Most people only consider careers they are familiar with or know people who are in those careers. When I spoke with the former chan- cellor, he spoke highly of one of the librarians at the university, so I spoke with her. I also spoke with my major professor who told me that his wife had an interest in the profession. The more people I talked with, the more excited I became.

One of the most important things I learned from the experience is the value of creating positive images, interactions, and experiences with faculty and students in the academic environment. We have the power to change perceptions through our interactions in reference, faculty liaison, university-sponsored events, and committees. Our colleagues in universities and colleges are the ones who have ongoing direct contact with potential library and information science students. I never would have considered librarianship had it not been for the encouragement of those important people in my life.-Kay Tavill, instnuctional materials librarian, Loyola University conveyed may be totally different than when a career counselor describes a librarian, or when a librarian describes a librarian. The information could come from a place closer to home when a student asks a parent, "What do you think about my applying to graduate school in Information and Library Studies?" and the reply is, "How much is it going to cost and will you be guaranteed a high-paying job when you finish?"

As information professionals know, access to information is a key element in developing

\section{"How much is it going to cost and will you be guaranteed a bigh- paying job when you finish?"}

a knowledge base. Providing effective means for a student to access information about library careers can be based on knowledge about students in general. In designing programs and services to help students and recruiters communicate, career counselors pay attention to cognitive differences, learning style preferences, and differences in level of career maturity, in addition to other characteristics. For example, a first year student will most probably need a different type of information than a graduate student. Some students learn best from experience, others from research, others through conversation. A student who has had an internship experience will have a different sense of career reality than someone who has not had that experience. So, in tackling the question about how students perceive and consequently choose any given career, we also look at individual differences.

Strategies for effective programs, resources, and services designed to showcase your profession can be enhanced by incorporating both a knowledge of the career decision-making process and insight into individual differences. Based on this type of insight, I would like to offer the following strategies for exposing students to the library profession:

- Consider all of the existing mecbanisms within your workplace that can introduce students to a realistic view of your profession.

Look for opportunities where students (individually or in groups) can gain a realistic picture of what you do. You can provide information to student workers as you serve as a role model. Consider opportunities in bibliographic instruction courses where you can give insight on the role of the librarian in the process. 
- Provide information about your profession in a variety of formats and styles.

As students look for information some may be more comfortable with materials in print, others may prefer interactions with individuals, and still others may like information provided through different types of technologye.g., computer conferences - or you may consider utilizing combinations of formats; displays as well as information sessions, for example.

- Develop experiential learning opportunities which will allow students bands-on access to your profession.

Opportunities such as internships, informational interviews or shadowing programs will allow students to test out their interests and gain a broader picture of what the profession encompasses.

- Provide information about the education required in your profession.

As mentioned previously, this information should be delivered in a variety of formats and styles. Often, graduate programs will work hand in hand with people within the profession to develop information provided in graduate school literature, special career information days, or campus visits. Additionally, many career planning and placement offices provide programs on graduate school where students can collect information about a variety of options.
- Target students botb where they study and where they live.

Students spend a great deal of their time in academic buildings, student unions, and residence halls. Consider all of these locations and other high-traffic areas on your campus when making decisions about information dissemination.

- Utilize career planning and placement professionals in providing information and designing strategies.

Career planning and placement offices often provide a variety of resources that enable a student to explore careers and make decisions about graduate education. By providing your career office up-to-date and realistic information about the library profession, in addition to taking advantage of established services and utilizing the staff to build new strategies, you can design a plan that will reach a great number of students.

Attracting students to the library profession can be a rewarding process. It challenges the profession to provide a realistic view of itself which can be easily translated to students. In the process of communicating timely, accurate, and enlightening information, both those who send the message about careers in the library profession and those who receive it will enrich their knowledge of the world of work and of the important roles that are played.

\section{Antonetti wins Nifhoff awand}

Martin Antonetti is the recipient of the 1992 Martinus Nijhoff West European Specialist Study Grant. The grant covers air travel to and from Europe, transportation in Europe, and lodging and board for 14 consecutive days. Antonetti will receive his award at the ALA Annual Conference in San Francisco during the WESS annual program and membership meeting on June 29, 1992 at 2:00 p.m.

"Mr. Antonetti's project involves opening channels of communication and establishing commercial and cultural ties between American fine press and avant-garde publishers with their counterparts in Italy, with the goal of bringing the products of these to United States libraries," said Eva Sartori, chair of the award jury. "The texts published by Italian fine press and avantgarde publishers presently exist completely outside the main distribution networks and are not even well known in Italy itself. Mr. Antonetti will visit Italian printers and publishers, discuss the creation of their lists, examine their works, and discuss with them the ways in which their works can be brought to the United States."

Antonetti received his MLS from Columbia University and his B.A. in ancient and medieval history from Western Kentucky University. $\mathrm{He}$ is a specialist in the history of printing and is assistant director of Columbia University's Rare Book School. Antonetti is currently librarian of the Grolier Club, one of the most comprehensive collections of books about books in the United States.

The grant is awarded to an ALA member to study some aspect of West European studies, librarianship, or the book trade. 